\title{
Chemical Characterization of Lignin and Lipophilic Fractions from Leaf Fibers of Curaua (Ananas erectifolius)
}

\author{
Gisela Marques, Ana Gutiérrez, and José C. Del Río* \\ Instituto de Recursos Naturales y Agrobiología de Sevilla, CSIC, P.O. Box 1052, 41080 Seville, Spain
}

\begin{abstract}
The chemical composition of leaf fibers of curaua (Ananas erectifolius), an herbaceous plant native of Amazonia, was studied. Special attention was paid to the content and composition of lignin and lipophilic compounds. The analysis of lignin in the curaua fibers was performed in situ by pyrolysisgas chromatography/mass spectrometry (Py-GC/MS) and showed a lignin composition with a p-hydroxyphenyl:guaiacyl:syringyl units (H:G:S) molar proportion of 30:29:41 (S/G molar ratio of 1.4). The presence of $p$-hydroxycinnamic acids ( $p$-coumaric and ferulic acids) in curaua fibers was revealed upon pyrolysis in the presence of tetramethylammonium hydroxide. On the other hand, the main lipophilic compounds, analyzed by GC/MS, were series of long-chain $n$-fatty acids, $n$-fatty alcohols, $\alpha$ - and $\omega$-hydroxyacids, monoglycerides, sterols, and waxes. Other compounds, such as $\omega$-hydroxy monoesters and $\omega$-hydroxy acylesters of glycerol, were also found in this fiber in high amounts.
\end{abstract}

KEYWORDS: Curaua; Ananas erectifolius; lipids; lignin; pyrolysis; hydroxy monoesters; glyceryl esters; paper pulp

\section{INTRODUCTION}

An alternative to wood raw materials for pulp and paper production in developing countries is the use of nonwoody fibers from herbaceous field crops. In developed countries, nonwoody fibers are mainly used for the production of specialty papers, i.e., tea bags, filter papers, bank notes, etc. The main sources of nonwoody raw materials are agricultural residues from monocotyledons, including cereal straw and bagasse. Bamboo, reeds, and some other grass plants such as flax, hemp, kenaf, jute, sisal, or abaca are also grown or collected for the pulp industry, but increased attention has been paid in recent years to find new nonwood raw materials for pulp production.

Curaua (Ananas erectifolius), an herbaceous plant native of the Amazonian region and a member of the bromeliad family, has been recognized since pre-Columbian days for its valuable fibers $(1-4)$. In the past decade, it has gained commercial recognition as a material for composites for the automotive industry $(2,4)$. The curaua fiber has also been promoted for paper pulp in Brazil, and it is now being investigated as an alternative lignocellulosic material for the production of chemical pulps.

Studies on the chemical composition of curaua fibers are important to evaluate this fiber as a potential raw material for pulp and papermaking; however, only limited studies have been performed so far on this interesting fiber $(1,3,5)$. In this work, we have performed a chemical characterization of curaua fibers, paying special attention to the content and composition of the lipophilic compounds and the structural characterization of lignin, since these two organic fractions are of high importance

* To whom correspondence should be addressed. Tel: +34954624711. Fax: +34 95462 4002. E-mail: delrio@irnase.csic.es. during pulping and papermaking. It is known that the efficiency of pulping is directly proportional to the amount of syringyl (S) units in lignin $(6,7)$. This is because the S-lignin is mainly linked by more labile ether bonds, is relatively unbranched, and has a lower condensation degree than G-lignin $(8,9)$. Indeed, the S-lignin has a higher reactivity in alkaline systems than G-lignin (10). On the other hand, the lipophilic compounds present in raw materials cause significant environmental and technical problems in the manufacturing of paper pulp. During pulping, lipids are released from the fibers forming colloidal pitch, which can deposit in either pulp or machinery, causing production troubles $(11-13)$. Moreover, such extractives might also contribute to the toxicity of paper pulp effluents and products $(14,15)$.

In the present study, the lignin in curaua fibers was characterized in situ by using analytical pyrolysis coupled to gas chromatography/mass spectrometry (Py-GC/MS), which is a powerful analytical tool for the rapid analysis of complex polymer mixtures, including lignocellulosic materials $(16,17)$. Pyrolysis in the presence of a methylating reagent, tetramethylammonium hydroxide (TMAH), was used for the analysis of $p$-hydroxicinnamic acids ( $p$-coumaric and ferulic acids). On the other hand, the lipid composition in curaua fibers was analyzed by GC and GC/MS, using short- and medium-length hightemperature capillary columns, respectively (18), which enable the elution and analysis of intact high molecular weight lipids such as waxes, sterol esters, and triglycerides.

\section{MATERIALS AND METHODS}

Samples. Curaua (A. erectifolius) fibers were supplied by CELESA pulp mill (Tortosa, Spain). The dried samples were milled using a knife mill (Janke and Kunkel, Analyzenmühle). For the isolation of lipids, the milled samples were extracted with acetone in a Soxhlet apparatus 


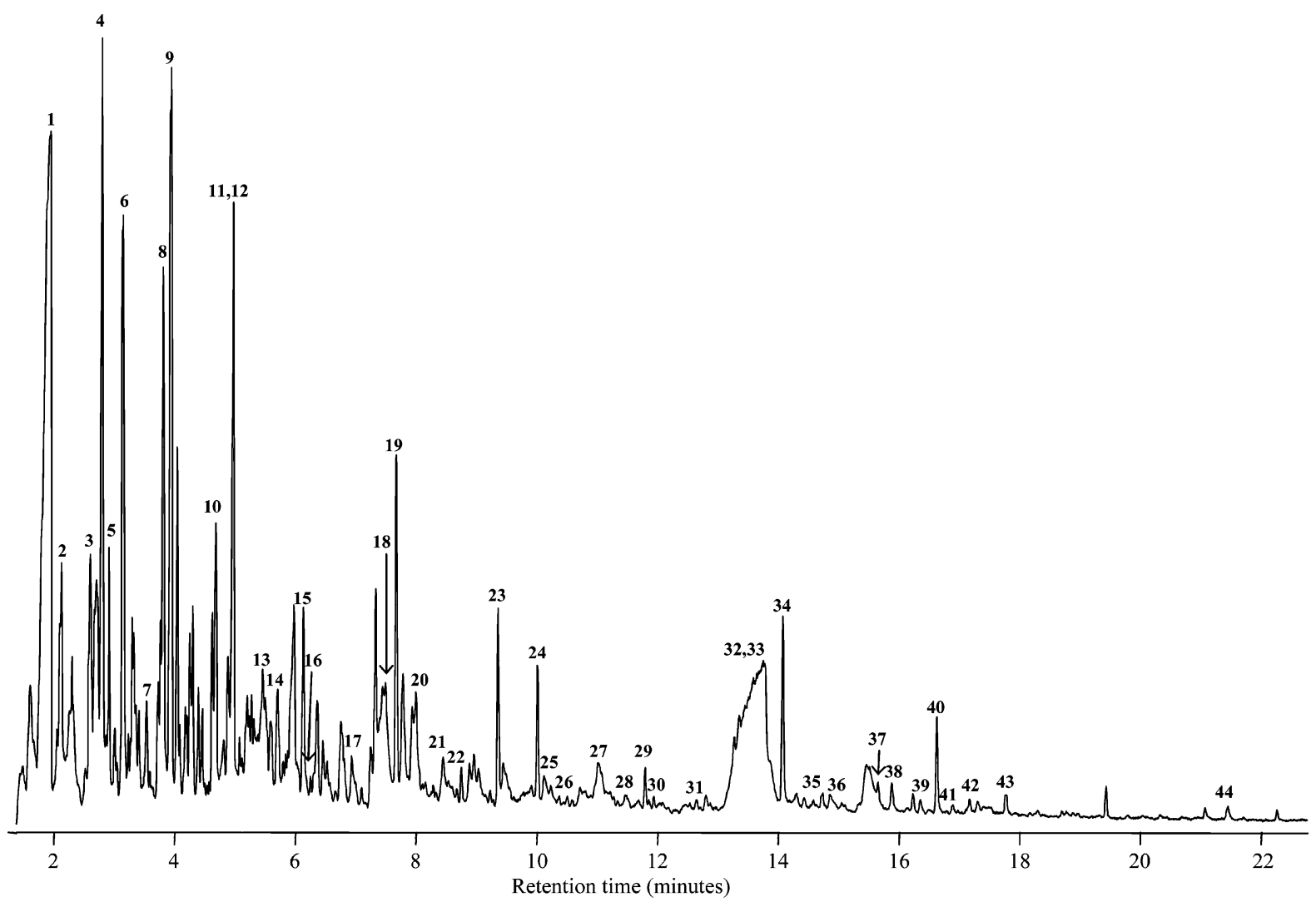

Figure 1. Py-GC/MS chromatogram of curaua fibers. The identities and relative molar abundances of the compounds are listed in Table 1.

for $8 \mathrm{~h}$. The acetone extracts were evaporated to dryness and weighted. Then, the extracts were resuspended in chloroform for chromatographic analysis of the lipophilic fraction. Two replicates were used for each sample, and all samples were subjected to GC and GC/MS analyses. For carbohydrate analysis and estimation of the Klason lignin content, the acetone-extracted samples were subsequently extracted with hot water $\left(3 \mathrm{~h}\right.$ at $\left.100{ }^{\circ} \mathrm{C}\right)$ to remove the water-soluble material. Holocellulose was isolated from the pre-extracted fibers by delignification for $4 \mathrm{~h}$ using the acid chlorite method (19). The $\alpha$-cellulose content was determined by removing the hemicelluloses from the holocellulose by alkali extraction (19). Klason lignin was estimated as the residue after sulfuric acid hydrolysis of the pre-extracted material according to Tappi rule T222 om-88 (20). The acid-soluble lignin was determined, after the insoluble lignin was filtered off, by spectrophotometric determination at $205 \mathrm{~nm}$ wavelength. Neutral sugars from polysaccharide hydrolysis were analyzed as alditol acetates by GC according to Tappi rule T249 om85 (20). The ash content was estimated as the residue after $6 \mathrm{~h}$ at $575^{\circ} \mathrm{C}$. The general composition (as percent of whole fiber) was as follows: holocellulose, $92.5 \%$; $\alpha$-cellulose, $66.4 \%$; ash, $1.3 \%$; acetone extractives, $5.3 \%$; water-soluble extract, $5.1 \%$; Klason lignin, $4.9 \%$; and acid-soluble lignin, $1.6 \%$. The composition of neutral monosaccharides (as percent of total neutral carbohydrates) included arabinose, $2.7 \%$; xylose, $8.0 \%$; mannose, $3.5 \%$; galactose, $0.2 \%$; and glucose, $85.6 \%$. No uronic acid determination was performed in this study. The composition of metals and other elements was analyzed by inductively coupled plasma spectrophotometry after oxidation with concentrated $\mathrm{HNO}_{3}$ under pressure in a microwave digestor, with the following results: K, 2770 ppm; Ca, 2025 ppm; Mg, 945 ppm; Mn, 120 ppm; Na, 95 ppm; Al, 86 ppm; Fe, 82 ppm; Sr, 10 ppm; and Zn, 4 ppm.

Solid-Phase Extraction (SPE) Fractionation. For a better characterization of the different homologous series, the lipid extracts were fractionated by a SPE procedure using aminopropyl-phase cartridges (500 mg) from Waters Division of Millipore (Mildford, MA), as already described (18). Briefly, the dried chloroform extracts were taken up in a minimal volume $(<0.5 \mathrm{~mL})$ of hexane:chloroform $(4: 1)$ and loaded into the cartridge column previously conditioned with hexane $(4 \mathrm{~mL})$. The cartridge was loaded and eluted by gravity. The column was first eluted with $8 \mathrm{~mL}$ of hexane and subsequently with $6 \mathrm{~mL}$ of hexane: chloroform (5:1), then with $10 \mathrm{~mL}$ of chloroform and finally with 10 $\mathrm{mL}$ of diethyl ether:acetic acid (98:2). Each isolated fraction was dried under nitrogen and analyzed by GC and GC/MS.

GC and GC/MS Analyses. The GC analyses of the extracts were performed in an Agilent $6890 \mathrm{~N}$ Network GC system using a $5 \mathrm{~m} \times$ $0.25 \mathrm{~mm}$ i.d., $0.1 \mu \mathrm{m}$ DB-5HT fused silica capillary column from $\mathrm{J} \& \mathrm{~W}$ Scientific (Folsom, CA). The temperature program was started at 100 ${ }^{\circ} \mathrm{C}$ with a $1 \mathrm{~min}$ hold and then raised to a final temperature of $350{ }^{\circ} \mathrm{C}$ at $15{ }^{\circ} \mathrm{C} / \mathrm{min}$, and held for $3 \mathrm{~min}$. The injector and flame ionization detector temperatures were set at 300 and $350{ }^{\circ} \mathrm{C}$, respectively. Helium was used as the carrier gas at a rate of $5 \mathrm{~mL} / \mathrm{min}$, and the injection was performed in splitless mode. Peaks were quantified by area, and a mixture of standards (octadecane, palmitic acid, sitosterol, and cholesteryl oleate) was used to elaborate calibration curves. The data from the two replicates were averaged. In all cases, the standard derivations from replicates were below $10 \%$ of the mean values.

The GC/MS analyses were performed with a Varian model Star 3400 GC equipped with a model Saturn 2000 ion trap detector using a medium-length $(12 \mathrm{~m})$ capillary column of the same characteristics described above. The oven was heated from $120(1 \mathrm{~min})$ to $380{ }^{\circ} \mathrm{C}$ at $10{ }^{\circ} \mathrm{C} / \mathrm{min}$ and held for $5 \mathrm{~min}$. The transfer line was kept at $300{ }^{\circ} \mathrm{C}$. The injector was temperature programmed from $120(0.1 \mathrm{~min})$ to 380 ${ }^{\circ} \mathrm{C}$ at a rate of $200{ }^{\circ} \mathrm{C} / \mathrm{min}$ and held until the end of the analysis. Helium was used as the carrier gas at a rate of $2 \mathrm{~mL} / \mathrm{min}$. Methylation with trimethylsilyldiazomethane and silylation with bis(trimethylsilyl)trifluoroacetamide (BSTFA) was used when required. Compounds were identified by comparing their mass spectra with mass spectra in Wiley and NIST libraries, by mass fragmentography, and when possible, by comparison with authentic standards.

Py-GC/MS. The pyrolysis of curaua fibers (approximately $100 \mu \mathrm{g}$ ) was performed in duplicate with a model 2020 microfurnace pyrolyzer (Frontier Laboratories Ltd., Yoriyama, Japan) directly connected to an Agilent $6890 \mathrm{GC} / \mathrm{MS}$ system equipped with a $30 \mathrm{~m} \times 0.25 \mathrm{~mm}$ i.d., $0.25 \mu \mathrm{m}$ HP 5MS fused silica capillary column. The detector consisted of an Agilent 5973 mass selective detector (EI at $70 \mathrm{eV}$ ). The pyrolysis was performed at $500{ }^{\circ} \mathrm{C}$. The final temperature was achieved at a rate of $20^{\circ} \mathrm{C} / \mathrm{min}$. The GC/MS conditions were as follows: oven temper- 
Table 1. Identification and Relative Molar Abundances (\%) of the Compounds Released after Py-GC/MS of Curaua Fibers ${ }^{a}$

\begin{tabular}{|c|c|c|c|c|c|}
\hline no. & compound & mass fragments & MW & origin & $\%$ \\
\hline 1 & acetic acid & $45 / 60$ & 60 & C & 35.8 \\
\hline 2 & 2-hydroxypropanal & $43 / 74$ & 74 & C & 3.1 \\
\hline 3 & $(3 H)$-furan-2-one & $55 / 84$ & 84 & C & 3.1 \\
\hline 4 & 1,3-hydroxydihydro-2-(3H)-furanone & $58 / 102$ & 102 & C & 6.0 \\
\hline 5 & $(2 \mathrm{H})$-furan-3-one & $55 / 84$ & 84 & C & 1.4 \\
\hline 6 & 2-furaldehyde & $67 / 95 / 96$ & 96 & C & 6.4 \\
\hline 7 & cyclopent-1-ene-3,4-dione & $54 / 68 / 96$ & 96 & C & 0.9 \\
\hline 8 & $(5 \mathrm{H})$-furan-2-one & $55 / 84$ & 84 & C & 4.2 \\
\hline 9 & 2,3-dihydro-5-methylfuran-2-one & $55 / 69 / 98$ & 98 & C & 8.5 \\
\hline 10 & 4-hydroxy-5,6-dihydro-(2H)-pyran-2-one & $58 / 85 / 114$ & 114 & C & 2.1 \\
\hline 11 & 3-hydroxy-2-methyl-2-cyclopenten-1-one & $55 / 85 / 112$ & 112 & C & 1.1 \\
\hline 12 & 2-hydroxy-3-methyl-2-cyclopenten-1-one & $55 / 85 / 112$ & 112 & C & 4.8 \\
\hline 13 & 4-methylphenol & 77/107/108 & 108 & $\mathrm{LH}$ & 0.7 \\
\hline 14 & guaiacol & $81 / 109 / 124$ & 124 & LG & 0.5 \\
\hline 15 & 2-furoic acid, methyl ester & $67 / 95 / 126$ & 126 & C & 1.3 \\
\hline 16 & 4-methylguaiacol & $95 / 123 / 138$ & 138 & LG & 0.1 \\
\hline 17 & 3,4-dihydroxybenzaldehyde & $81 / 109 / 137 / 138$ & 138 & $\mathrm{~L}$ & 0.5 \\
\hline 18 & catechol & $64 / 81 / 92 / 110$ & 110 & $\mathrm{~L} / \mathrm{C}$ & 1.0 \\
\hline 19 & 4-vinylphenol & $65 / 91 / 120$ & 120 & $\mathrm{LH} / p C A$ & 2.2 \\
\hline 20 & 5-hydroxymethyl-2-furaldehyde & $69 / 97 / 109 / 126$ & 126 & $\mathrm{C}$ & 1.9 \\
\hline 21 & 3-methoxycatechol & $60 / 97 / 125 / 140$ & 140 & L & 0.3 \\
\hline 22 & 4-ethylguaiacol & $122 / 137 / 152$ & 152 & LG & 0.2 \\
\hline 23 & 4-vinylguaiacol & $107 / 135 / 150$ & 150 & LG & 1.1 \\
\hline 24 & syringol & $111 / 139 / 154$ & 154 & LS & 0.7 \\
\hline 25 & eugenol & $131 / 149 / 164$ & 164 & LG & 0.2 \\
\hline 26 & 4-propylguaiacol & $122 / 136 / 166$ & 166 & LG & $<0.1$ \\
\hline 27 & vanillin & $109 / 151 / 152$ & 152 & LG & 0.3 \\
\hline 28 & cis-isoeugenol & $131 / 149 / 164$ & 164 & LG & $<0.1$ \\
\hline 29 & 4-methylsyringol & $125 / 153 / 168$ & 168 & LS & 0.2 \\
\hline 30 & trans-isoeugenol & $131 / 149 / 164$ & 164 & LG & 0.1 \\
\hline 31 & acetoguaiacone & $123 / 151 / 166$ & 166 & LG & 0.1 \\
\hline 32 & levoglucosane & $60 / 98$ & 162 & $\mathrm{C}$ & 7.7 \\
\hline 33 & 4-ethylsyringol & $167 / 182$ & 182 & LS & 0.8 \\
\hline 34 & 4-vinylsyringol & $137 / 165 / 180$ & 180 & LS & 0.9 \\
\hline 35 & 4-allylsyringol & $167 / 179 / 194$ & 194 & LS & 0.1 \\
\hline 36 & 4-propylsyringol & $123 / 167 / 196$ & 196 & LS & 0.1 \\
\hline 37 & cis-4-propenylsyringol & 167/179/194 & 194 & LS & 0.2 \\
\hline 38 & syringaldehyde & $167 / 181 / 182$ & 182 & LS & 0.2 \\
\hline 39 & 4-propinylsyringol & 106/131/177/192 & 192 & LS & 0.1 \\
\hline 40 & trans-4-propenylsyringol & $167 / 179 / 194$ & 194 & LS & 0.5 \\
\hline 41 & trans-coniferaldehyde & $107 / 135 / 147 / 178$ & 178 & LG & 0.1 \\
\hline 42 & acetosyringone & $153 / 181 / 196$ & 196 & LS & 0.1 \\
\hline 43 & syringylacetone & $123 / 167 / 210$ & 210 & LS & 0.1 \\
\hline \multirow[t]{8}{*}{44} & trans-sinapaldehyde & $137 / 165 / 180 / 208$ & 208 & LS & 0.1 \\
\hline & $\% \mathrm{H}$ & & & & 29.8 \\
\hline & $\% G$ & & & & 29.1 \\
\hline & $\% S$ & & & & 41.1 \\
\hline & $S / G$ & & & & 1.4 \\
\hline & $\% \mathrm{~L}$ & & & & 11.7 \\
\hline & $\% \mathrm{C}$ & & & & 88.3 \\
\hline & $\mathrm{L} / \mathrm{C}$ & & & & 0.13 \\
\hline
\end{tabular}

\begin{abstract}
${ }^{a}$ Mass fragments, molecular weight (MW), origin, and relative molar abundances guaiacyl lignin units, G; LS, syringyl lignin units, $\mathrm{S}$; and pCA, p-coumaric acid.

ature was held at $50{ }^{\circ} \mathrm{C}$ for $1 \mathrm{~min}$ and then increased up to $100{ }^{\circ} \mathrm{C}$ at $30{ }^{\circ} \mathrm{C} / \mathrm{min}$, from 100 to $300{ }^{\circ} \mathrm{C}$ at $10{ }^{\circ} \mathrm{C} / \mathrm{min}$, and isothermal at 300 ${ }^{\circ} \mathrm{C}$ for $10 \mathrm{~min}$. The carrier gas used was helium with a controlled flow of $1 \mathrm{~mL} / \mathrm{min}$. For the pyrolysis in the presence of TMAH, approximately $100 \mu \mathrm{g}$ of sample was mixed with $0.5 \mu \mathrm{L}$ of $25 \% \mathrm{TMAH}$. The pyrolysis was carried out as described above. The compounds were identified by comparing the mass spectra obtained with those of the Wiley and NIST computer libraries and that reported in the literature $(16,17)$. Relative peak molar areas were calculated for carbohydrate and lignin pyrolysis products. The summed molar areas of the relevant peaks were normalized to $100 \%$, and the data for two repetitive pyrolysis experiments were averaged. The relative standard deviation for the pyrolysis data was less than $5 \%$.
\end{abstract}

\section{RESULTS AND DISCUSSION}

The curaua fiber was characterized by high holocellulose and $\alpha$-cellulose contents (92.5 and 66.4, respectively) and a low lignin content $(6.5 \%$ of the total fiber weight). This lignin content is similar to other nonwood fibers such as flax or hemp and lower than other nonwood fibers such as kenaf or abaca $(21-26)$. The extractives content $(5.3 \%$ of total fiber weight $)$ is very high and much higher than other nonwood fibers, which are usually less than $1 \%(21-26)$. However, most of the acetone extract corresponds to polar compounds, while only $1.3 \%$ corresponded to lipophilic compounds, which were estimated by redissolving the acetone extracts in chloroform. On the other hand, the hemicellulose fraction was mainly constituted by xylose. Finally, the ash content (1.3\% of total fiber weight) was low in comparison to cereal straw (27), and the composition of the different metals revealed a predominance of $\mathrm{Ca}$ and $\mathrm{K}$ and a very low content of other metals.

Lignin Composition. The lignin composition of curaua fibers was analyzed in situ by Py-GC/MS. The Py-GC/MS chromato- 


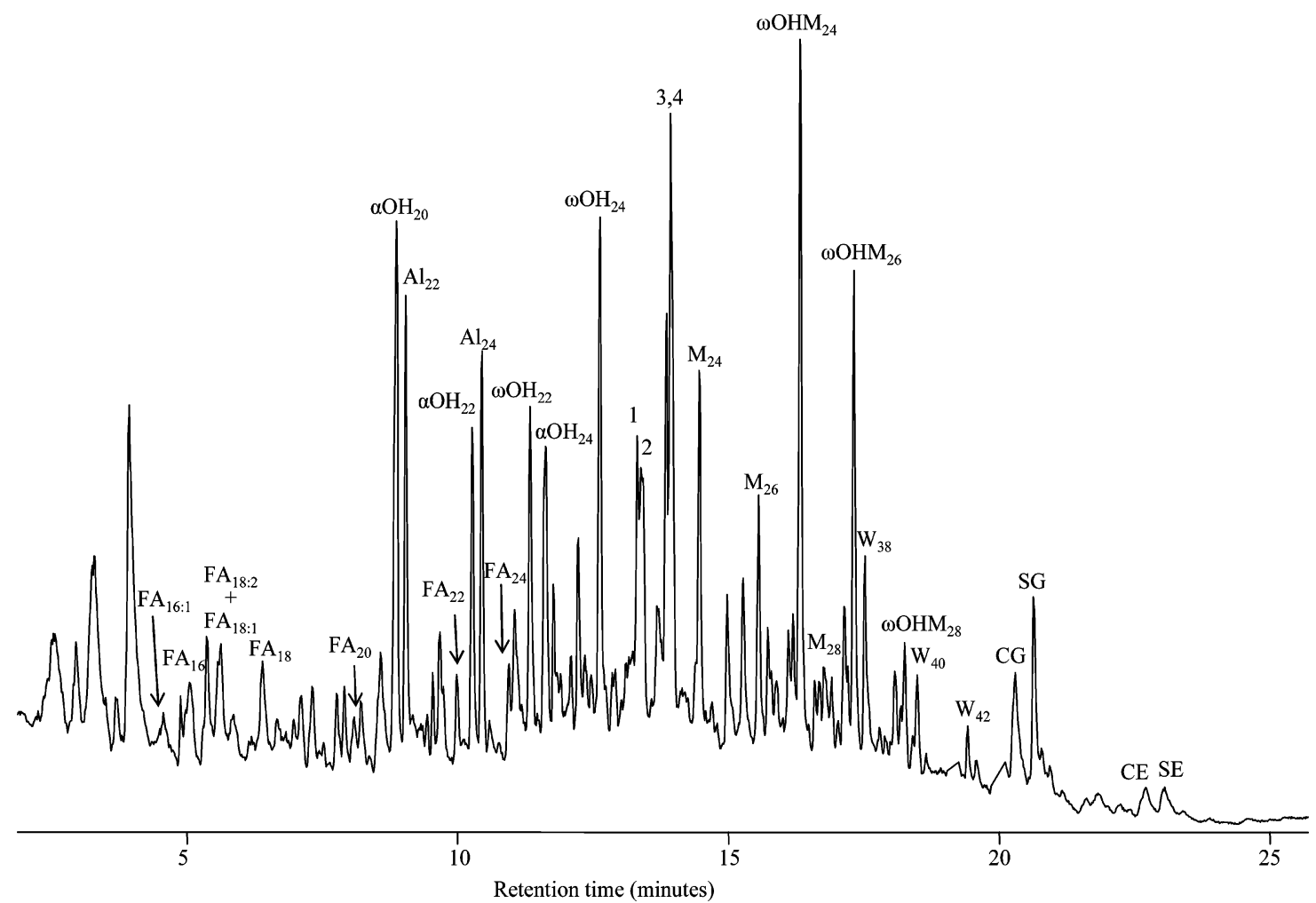

Figure 2. GC/MS chromatogram of the methyl ester and TMSi ether derivative of the lipid extract from curaua fibers. $\mathrm{FA}_{(n)}, n$-fatty acid series; $\mathrm{Al}_{(n)}$, alcohol series; $\mathrm{W}_{(n)}$, wax series; $\alpha \mathrm{OH}_{(n)}$ and $\omega \mathrm{OH}_{(n)}, \alpha$ - and $\omega$-hydroxy fatty acids series; $\mathrm{M}_{(n)}$, monoglyceride series; $\omega \mathrm{OHM} \mathrm{M}_{(n)}, \omega$-hydroxy acylesters of glycerol series; SG, sitosteryl 3 $\beta$-D-glucopyranoside; CG, campesteryl 3 $\beta$-D-glucopyranoside; 1, campesterol; 2, ergostanol; 3, sitosterol; 4, stigmastanol; $\mathrm{CE}$, campesterol ester; and SE, sitosterol ester; $n$ denotes the total carbon atom number.

gram of curaua fibers is shown in Figure 1, and the identities and relative molar abundances of the released compounds are listed in Table 1. The Py-GC/MS of curaua fibers released predominantly compounds arising from carbohydrates, with only minor amounts of lignin-derived phenols. Carbohydrate pyrolysis products represented $88 \%$ on average, and phenols from lignin represented only $12 \%$ of the total identified compounds, which is in agreement with the low lignin content estimated as Klason lignin. Among the lignin-derived compounds, the pyrogram of curaua fibers showed compounds derived from p-hydroxyphenyl $(\mathrm{H})$, guaiacyl $(\mathrm{G})$, and syringyl $(\mathrm{S})$ lignin units, with a slight predominance of the $S$ units. The main ligninderived compounds identified were 4-methylphenol (13), guaiacol (14), 4-vinylphenol (19), 4-vinylguaiacol (23), syringol (24), 4-ethylsyringol (33), 4-vinylsyringol (34), and trans-4-propenylsyringol (40). The relative molar distributions of the different lignin units (H:G:S) estimated by Py-GC/MS were 30: 29:41 with a S/G molar ratio of 1.4 . The predominance of S-lignin observed in the curaua fiber is advantageous for delignification during pulping because the S-lignin is relatively unbranched and has a lower condensation degree than $\mathrm{H}$ - and G-lignins. Moreover, S-lignin is more reactive in alkaline media (10).

It must be noted that the relatively high abundances of 4-vinylphenol (19) observed in the pyrogram of curaua fibers could be due to the presence of $p$-coumaric acid, which upon pyrolysis will decarboxylate to produce 4-vinylphenol (28). $p$-Hydroxycinnamic acids ( $p$-coumaric and ferulic acids) occur widely in the cell walls of herbaceous plants forming crosslinkages between lignin and polysaccharides (29-34). The presence of $p$-hydroxycinnamic acids constitutes a complication for lignin analyses by analytical pyrolysis since they yield pyrolysis products similar to those of corresponding lignin units.
However, this problem can be solved by the use of pyrolysis in the presence of TMAH (Py/TMAH), which prevents decarboxylation and releases intact $p$-hydroxycinnamic acids (as their methyl derivatives), in addition to different lignin degradation products $(28,35-38)$.

Py/TMAH of curaua fibers released significant amounts of the methyl derivative of $p$-coumaric acid $(25 \%$ of the lignin and cinnamic acids released products) as well as minor amounts of the methyl derivative of ferulic acid (5\% of the lignin and cinnamic acids released products). $p$-Hydroxycinnamic acids are present in curaua fiber in relatively high amounts (cinnamic acids/lignin ratio of 0.4 , estimated after Py/TMAH) and agree with the relatively high content of 4-vinylphenol released by Py-GC/MS. Studies on maize (39), wheat (40), and other grasses including bamboo (41) revealed that $p$-coumaric acid is esterified at the $\gamma$-position of lignin side chains and predominantly to $\mathrm{S}$ units $(41,42)$. Therefore, probably the major part of the $p$-coumaric acid in curaua fibers also attaches at the $\gamma$-position of the lignin side chain by ester bonds. The relatively high content of $p$-hydroxycinnamic acids in curaua fibers would also be advantageous for pulping since ester bonds are easily cleaved during cooking.

Lipid Composition. The total lipid extract of the curaua fibers accounted for $1.3 \%$ of the total fiber weight. The extracts were analyzed by GC and GC/MS according to the method developed by Gutiérrez et al. (18). The chromatogram of the curaua extracts (as methyl ester and TMSi ether derivatives) is shown in Figure 2, and the detailed list with the identities and abundances of the main compounds present is summarized in Table 2. The main compounds identified were series of $n$-fatty acids, $n$-fatty alcohols, $\alpha$ - and $\omega$-hydroxyacids, monoglycerides, sterols, and waxes. Other series of high molecular weight compounds such as $\omega$-hydroxy monoesters and $\omega$-hydroxy 
Table 2. Composition and Abundance $(\mathrm{mg} / \mathrm{kg})$ of Lipophilic Compounds in Curaua Fibers ${ }^{a}$

\begin{tabular}{|c|c|c|c|c|c|c|c|}
\hline compound & $\begin{array}{l}\text { mass fragments } \\
(\mathrm{m} / \mathrm{z})\end{array}$ & MW & abundance & compound & $\begin{array}{l}\text { mass fragments } \\
(\mathrm{m} / \mathrm{z})\end{array}$ & MW & abundance \\
\hline \multicolumn{8}{|c|}{ fatty acids (total abundance, 813.2) } \\
\hline$n$-tetradecanoic acid & $60 / 73 / 129 / 228$ & 228 & 4.3 & 9-octadecenoic acid & $55 / 69 / 264$ & 282 & 91.6 \\
\hline$n$-pentadecanoic acid & 60/73/129/242 & 242 & 3.3 & $n$-octadecanoic acid & $60 / 73 / 129 / 284$ & 284 & 262.0 \\
\hline 9-hexadecenoic acid & $55 / 69 / 236 / 254$ & 254 & 7.6 & $n$-eicosanoic acid & 60/73/129/312 & 312 & 24.2 \\
\hline$n$-hexadecanoic acid & $60 / 73 / 129 / 256$ & 256 & 162.5 & $n$-docosanoic acid & $60 / 73 / 129 / 340$ & 340 & 138.2 \\
\hline 9,12-octadecadienoic acid & $67 / 81 / 280$ & 280 & 23.0 & $n$-tetracosanoic acid & $60 / 73 / 129 / 368$ & 368 & 96.5 \\
\hline \multicolumn{8}{|c|}{$\omega$-hydroxy fatty acids (total abundance, 1423.3) } \\
\hline 16-hydroxyhexadecanoic acid & 311/343/359\# & $374^{\#}$ & 20.2 & 24-hydroxytetracosanoic acid & $423 / 455 / 471^{\#}$ & $486^{\#}$ & 367.0 \\
\hline 18-hydroxyoctadecanoic acid & $339 / 371 / 387 \#$ & $402^{\#}$ & 28.4 & 26 -hydroxyhexacosanoic acid & 451/483/499\# & $514^{\#}$ & 532.5 \\
\hline 20-hydroxyeicosanoic acid & $367 / 399 / 415^{\#}$ & $430^{\#}$ & 30.8 & 28-hydroxyoctacosanoic acid & $479 / 511 / 527^{\#}$ & $542^{\#}$ & 119.2 \\
\hline 22-hydroxydocosanoic acid & $395 / 427 / 443^{\#}$ & $458^{\#}$ & 235.0 & 30-hydroxytriacontanoic acid & $507 / 539 / 555^{\#}$ & $570^{\#}$ & 90.2 \\
\hline \multicolumn{8}{|c|}{$\alpha$-hydroxy fatty acids (total abundance, 226.5) } \\
\hline $\begin{array}{l}\text { 2-hydroxyeicosanoic acid } \\
\text { 2-hydroxydocosanoic acid }\end{array}$ & $\begin{array}{l}73 / 117 / 355^{*} \\
73 / 117 / 149 / 383^{*}\end{array}$ & $\begin{array}{l}472^{*} \\
500^{*}\end{array}$ & $\begin{array}{l}62.7 \\
19.9\end{array}$ & $\begin{array}{l}\text { 2-hydroxytetracosanoic acid } \\
\text { 2-hydroxyhexacosanoic acid }\end{array}$ & $\begin{array}{l}73 / 117 / 411^{*} \\
73 / 117 / 439^{*}\end{array}$ & $\begin{array}{l}528^{*} \\
556^{*}\end{array}$ & $\begin{array}{l}79.2 \\
64.7\end{array}$ \\
\hline \multicolumn{8}{|c|}{ fatty alcohols (total abundance, 552.4) } \\
\hline$n$-eicosanol & $75 / 103 / 355^{*}$ & $370^{*}$ & 8.9 & $n$-hexacosanol & $75 / 103 / 439^{*}$ & $454^{*}$ & 44.3 \\
\hline$n$-docosanol & $75 / 103 / 383^{*}$ & $398^{*}$ & 247.2 & $n$-octacosanol & $75 / 103 / 467^{*}$ & $482^{*}$ & 9.8 \\
\hline$n$-tetracosanol & $75 / 103 / 411^{*}$ & $426^{*}$ & 242.2 & & & & \\
\hline \multicolumn{8}{|c|}{ sterols (total abundance, 618.7) } \\
\hline campesterol & $55 / 145 / 213 / 382 / 400$ & 400 & 56.9 & sitosterol & $145 / 213 / 396 / 414$ & 414 & 226.4 \\
\hline ergostanol & $215 / 402$ & 402 & 145.7 & stigmastanol & $215 / 416$ & 416 & 189.7 \\
\hline \multicolumn{8}{|c|}{ tocopherols (total abundance, 31.4) } \\
\hline$\alpha$-tocopherol & $165 / 205 / 430$ & 430 & 31.4 & (n) & & & \\
\hline \multicolumn{8}{|c|}{ steroid hydrocarbons (total abundance, 119.4) } \\
\hline ergostatriene & $135 / 143 / 380$ & 380 & 23.8 & stigmasta-3,5,22-triene & $135 / 143 / 394$ & 394 & 2.6 \\
\hline ergostadiene & $81 / 147 / 367 / 382$ & 382 & 14.4 & stigmasta-3,5-diene & $81 / 147 / 381 / 396$ & 396 & 6.8 \\
\hline stigmastadiene & $81 / 147 / 381 / 396$ & 396 & 71.8 & & & & \\
\hline \multicolumn{8}{|c|}{ steroid ketones (total abundance, 57.9) } \\
\hline stigmasta-3,5-dien-7-one & $174 / 269 / 410$ & 410 & 7.7 & stigmastadienone isomer & $57 / 136 / 174 / 269 / 410$ & 410 & 16.4 \\
\hline stigmast-4-en-3-one & $124 / 229 / 412$ & 412 & 24.4 & stigmastane-3,6-dione & $245 / 287 / 428$ & 428 & 9.4 \\
\hline \multicolumn{8}{|c|}{ sterol esters (total abundance, 89.4) } \\
\hline campesterol ester & & & 49.3 & sitosterol ester & & & 40.1 \\
\hline \multicolumn{8}{|c|}{ steryl glycosides (total abundance, 264.9) } \\
\hline $\begin{array}{l}\text { campesteryl } \\
\quad 3 \beta \text {-D-glucopyranoside }\end{array}$ & $204 / 217 / 361 / 383^{*}$ & $850^{*}$ & 141.3 & $\begin{array}{l}\text { sitosteryl } 3 \beta \text {-D-gluco- } \\
\text { pyranoside }\end{array}$ & $204 / 217 / 361 / 397^{\star}$ & $864^{*}$ & 123.6 \\
\hline \multicolumn{8}{|c|}{ waxes (total abundance, 173.2) } \\
\hline $\mathrm{C}_{36}$ & $201 / 229 / 257 / 285 / 536$ & 536 & 3.5 & $\mathrm{C}_{41}$ & $257 / 271 / 285 / 299 / 313 /$ & 606 & 2.3 \\
\hline & & & & & $327 / 341 / 355 / 606$ & & \\
\hline $\mathrm{C}_{37}$ & $243 / 257 / 550$ & 550 & 3.3 & $\mathrm{C}_{42}$ & $257 / 285 / 313 / 341 / 620$ & 620 & 24.9 \\
\hline $\mathrm{C}_{38}$ & $257 / 564$ & 564 & 56.8 & $\mathrm{C}_{42: 1}$ & $264 / 283 / 618$ & 618 & 1.2 \\
\hline $\mathrm{C}_{39}$ & $243 / 257 / 271 / 285 /$ & 578 & 5.9 & $\mathrm{C}_{43}$ & $257 / 271 / 285 / 299 / 313 /$ & 634 & 1.5 \\
\hline & 299/578 & & & & $327 / 355 / 369 / 634$ & & \\
\hline $\mathrm{C}_{40}$ & $257 / 285 / 313 / 592$ & 592 & 46.5 & $\mathrm{C}_{44}$ & $257 / 285 / 313 / 341 / 648$ & 648 & 19.1 \\
\hline $\mathrm{C}_{40: 1}$ & $264 / 283 / 590$ & 590 & 2.9 & $\mathrm{C}_{46}$ & $\begin{array}{l}257 / 285 / 313 / 341 / 369 / \\
397 / 676\end{array}$ & 676 & 5.3 \\
\hline \multicolumn{8}{|c|}{$\omega$-hydroxy monoesters (total abundance, 369.5) } \\
\hline $\mathrm{C}_{36}$ & $73 / 129 / 237 / 311 / 609^{*}$ & $624^{*}$ & 29.1 & $\mathrm{C}_{40}$ & $\begin{array}{c}73 / 129 / 237 / 311 / 339 / \\
367 / 395 / 665^{*}\end{array}$ & $680^{*}$ & 95.6 \\
\hline $\mathrm{C}_{37}$ & $73 / 129 / 237 / 311 / 623^{*}$ & $638^{*}$ & 3.0 & $\mathrm{C}_{42}$ & $\begin{array}{c}73 / 129 / 237 / 311 / 339 / \\
367 / 395 / 693^{*}\end{array}$ & $708^{*}$ & 11.7 \\
\hline $\mathrm{C}_{38}$ & $\begin{array}{c}73 / 129 / 237 / 311 / \\
339 / 637^{*}\end{array}$ & $652^{*}$ & 229.8 & $\mathrm{C}_{44}$ & $73 / 129 / 367 / 395 / 721^{*}$ & $736^{*}$ & 0.3 \\
\hline \multicolumn{8}{|c|}{ monoglycerides (total abundance, 714.6 ) } \\
\hline 1-monotetradecanoylglycerol & $\begin{array}{c}73 / 103 / 129 / 147 / \\
343 / 431^{*}\end{array}$ & $446^{*}$ & 5.1 & 1-monotetracosanoylglycerol & $\begin{array}{l}73 / 103 / 129 / 147 / 483 / \\
571^{*}\end{array}$ & $586^{*}$ & 179.3 \\
\hline 1-monohexadecanoylglycerol & $\begin{array}{c}73 / 103 / 129 / 147 / \\
371 / 459^{*}\end{array}$ & $474^{*}$ & 5.3 & 1-monohexacosanoylglycerol & $\begin{array}{l}\text { 73/103/129/147/511/ } \\
599^{*}\end{array}$ & $614^{*}$ & 168.2 \\
\hline 1-monooctadecanoylglycerol & $\begin{array}{c}73 / 103 / 129 / 147 / \\
399 / 487^{\star}\end{array}$ & $502^{*}$ & 5.3 & 1-monooctacosanoylglycerol & $\begin{array}{l}\text { 73/103/129/147/539/ } \\
627^{\star}\end{array}$ & $642^{*}$ & 23.4 \\
\hline 1-monoeicosanoylglycerol & $\begin{array}{c}73 / 103 / 129 / 147 / \\
427 / 515^{*}\end{array}$ & $530^{*}$ & 31.6 & 1-monotriacontanoylglycerol & $\begin{array}{l}73 / 103 / 129 / 147 / 567 / \\
655^{*}\end{array}$ & $670^{*}$ & 8.2 \\
\hline 1-monodocosanoylglycerol & $\begin{array}{c}73 / 103 / 129 / 147 / \\
455 / 543^{*}\end{array}$ & $558^{*}$ & 288.2 & & & & \\
\hline \multicolumn{8}{|c|}{$\omega$-hydroxy acylesters of glycerol (total abundance, 960.8) } \\
\hline $\begin{array}{l}\text { 1-mono(22-hydroxydoco- } \\
\text { sanoyl)glycerol }\end{array}$ & $\begin{array}{c}73 / 103 / 129 / 147 / 203 / \\
486 / 543 / 631^{*}\end{array}$ & $646^{*}$ & 116.8 & $\begin{array}{l}\text { 1-mono(26-hydroxyhexaco- } \\
\text { sanoyl)glycerol }\end{array}$ & $\begin{array}{c}73 / 103 / 129 / 147 / 203 / \\
542 / 599 / 687^{*}\end{array}$ & $702^{*}$ & 301.7 \\
\hline $\begin{array}{l}\text { 1-mono(24-hydroxytetraco- } \\
\text { sanoyl)glycerol }\end{array}$ & $\begin{array}{c}73 / 103 / 129 / 147 / 203 / \\
514 / 571 / 659^{*}\end{array}$ & $674^{*}$ & 482.8 & $\begin{array}{l}\text { 1-mono(28-hydroxyoctaco- } \\
\text { sanoyl)glycerol }\end{array}$ & $\begin{array}{c}73 / 103 / 129 / 147 / 203 / \\
570 / 627 / 715^{*}\end{array}$ & $730^{*}$ & 59.5 \\
\hline
\end{tabular}

\footnotetext{
${ }^{a}$ Key: tr, traces; * as TMSi ether derivates; \# as methyl ester and TMSi ether derivates.
} 
<smiles>CCCCCCCCCCCCCCCCCC(=O)O</smiles><smiles>[B]CCCCCCCCCCCCCCCCO</smiles><smiles>CCCCCCCCCCCCCCCCCCCCCCCCCCCCO</smiles><smiles>CCCCCCCCCCCCCCCCCCCCCCC(O)C(=O)O</smiles><smiles>CCCCCCCCCCCCCCCCCCCCCOC(=O)CCCCCCCCCCCCCCCCO</smiles><smiles>CCCCCCCCCCCCCCCCCCCCCCC(=O)OCC(O)C(O)O</smiles><smiles>O=C(CCCCCCCCCCCCCCCCCCCCCCCO)OCC(O)CO</smiles>

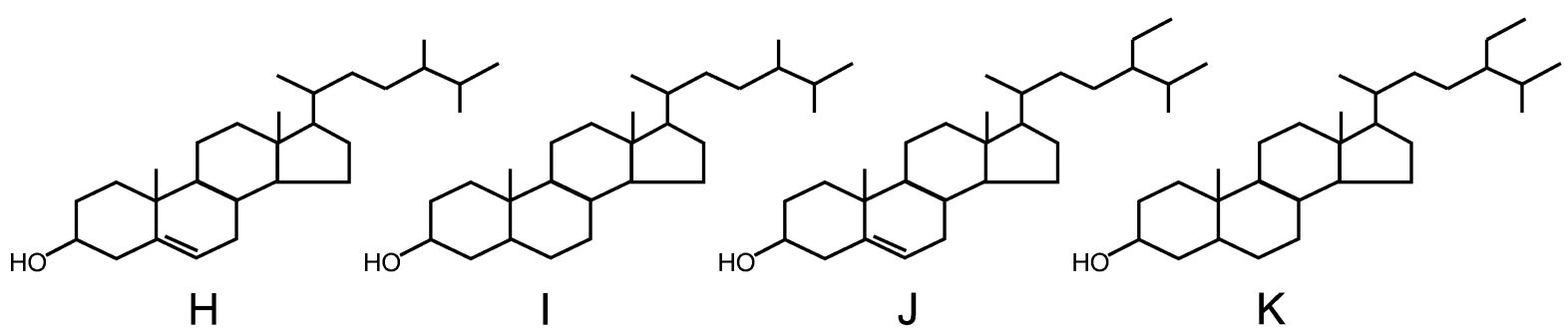

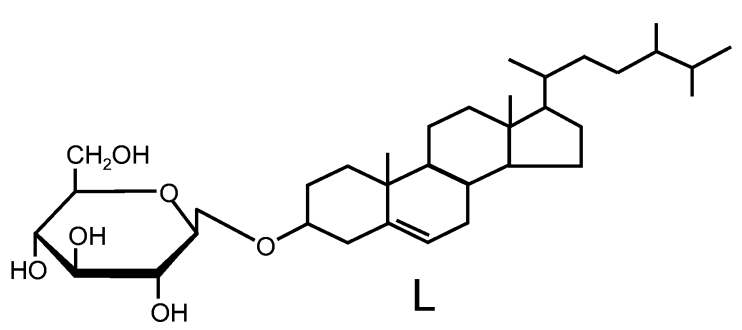

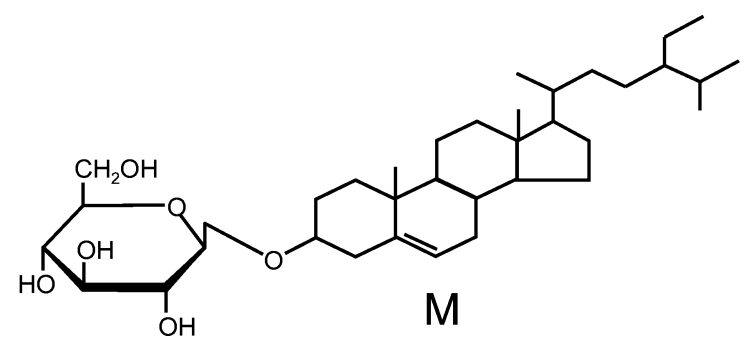

Figure 3. Structures of the main lipids present in the curaua fibers. (A) Stearic acid; (B) n-docosanol; (C) 26-hydroxyhexacosanoic acid; (D) 2-hydroxytetracosanoic acid; (E) docosanyl, 16-hydroxyhexadecanoate; (F) 1-monodocosanoylglycerol; (G) 1-mono(24-hydroxytetracosanoyl)glycerol; (H) campesterol; (I) ergostanol; (J) sitosterol; (K) stigmastanol; (L) campesteryl 3 $\beta$-D-glucopyranoside; and (M) sitosteryl 3 $\beta$-D-glucopyranoside. 
Table 3. Composition of the Different Waxes $(\mathrm{mg} / \mathrm{kg})$ Identified in Curaua Fibers ${ }^{a}$

\begin{tabular}{|c|c|c|}
\hline wax & fatty acid:fatty alcohol & abundance \\
\hline \multirow[t]{5}{*}{$\operatorname{wax} \mathrm{C}_{36}$} & & 3.5 \\
\hline & $\mathrm{C}_{12}: \mathrm{C}_{24}$ & 0.2 \\
\hline & $\mathrm{C}_{14}: \mathrm{C}_{22}$ & 1.1 \\
\hline & $\mathrm{C}_{16}: \mathrm{C}_{20}$ & 2.0 \\
\hline & $\mathrm{C}_{18}: \mathrm{C}_{18}$ & 0.2 \\
\hline \multirow[t]{3}{*}{ wax $\mathrm{C}_{37}$} & & 3.3 \\
\hline & $\mathrm{C}_{16}: \mathrm{C}_{21}$ & 0.9 \\
\hline & $\mathrm{C}_{15}: \mathrm{C}_{22}$ & 2.4 \\
\hline \multirow[t]{2}{*}{ wax $\mathrm{C}_{38}$} & & 56.8 \\
\hline & $\mathrm{C}_{16}: \mathrm{C}_{22}$ & 56.8 \\
\hline \multirow[t]{6}{*}{ wax $C_{39}$} & & 5.9 \\
\hline & $\mathrm{C}_{15}: \mathrm{C}_{24}$ & 0.9 \\
\hline & $\mathrm{C}_{16}: \mathrm{C}_{23}$ & 2.6 \\
\hline & $\mathrm{C}_{17}: \mathrm{C}_{22}$ & 2.2 \\
\hline & $\mathrm{C}_{18}: \mathrm{C}_{21}$ & 0.2 \\
\hline & $\mathrm{C}_{19}: \mathrm{C}_{20}$ & $<0.1$ \\
\hline \multirow[t]{4}{*}{ wax $\mathrm{C}_{40}$} & & 46.5 \\
\hline & $\mathrm{C}_{16}: \mathrm{C}_{24}$ & 25.3 \\
\hline & $\mathrm{C}_{18}: \mathrm{C}_{22}$ & 15.5 \\
\hline & $\mathrm{C}_{20}: \mathrm{C}_{20}$ & 5.7 \\
\hline \multirow[t]{2}{*}{ wax $C_{40: 1}$} & & 2.9 \\
\hline & $\mathrm{C}_{18: 1}: \mathrm{C}_{22}$ & 2.9 \\
\hline \multirow[t]{11}{*}{ wax $\mathrm{C}_{41}$} & & 2.3 \\
\hline & $\mathrm{C}_{15}: \mathrm{C}_{26}$ & 0.1 \\
\hline & $\mathrm{C}_{16}: \mathrm{C}_{25}$ & 0.6 \\
\hline & $\mathrm{C}_{17}: \mathrm{C}_{24}$ & 0.6 \\
\hline & $\mathrm{C}_{18}: \mathrm{C}_{23}$ & 0.4 \\
\hline & $\mathrm{C}_{19}: \mathrm{C}_{22}$ & 0.4 \\
\hline & $\mathrm{C}_{20}: \mathrm{C}_{21}$ & 0.2 \\
\hline & $\mathrm{C}_{21}: \mathrm{C}_{20}$ & $<0.1$ \\
\hline & $\mathrm{C}_{22}: \mathrm{C}_{19}$ & $<0.1$ \\
\hline & $\mathrm{C}_{23}: \mathrm{C}_{18}$ & $<0.1$ \\
\hline & $\mathrm{C}_{24}: \mathrm{C}_{16}$ & $<0.1$ \\
\hline \multirow[t]{5}{*}{ wax $\mathrm{C}_{42}$} & & 32.2 \\
\hline & $\mathrm{C}_{16}: \mathrm{C}_{26}$ & 3.4 \\
\hline & $\mathrm{C}_{18}: \mathrm{C}_{24}$ & 4.0 \\
\hline & $\mathrm{C}_{20}: \mathrm{C}_{22}$ & 22.1 \\
\hline & $\mathrm{C}_{22}: \mathrm{C}_{20}$ & 2.7 \\
\hline \multirow[t]{2}{*}{ wax $\mathrm{C}_{42: 1}$} & & 1.2 \\
\hline & $\mathrm{C}_{18: 1:}: \mathrm{C}_{24}$ & 1.2 \\
\hline \multirow[t]{12}{*}{ wax $\mathrm{C}_{43}$} & & 1.5 \\
\hline & $\mathrm{C}_{15}: \mathrm{C}_{28}$ & $<0.1$ \\
\hline & $\mathrm{C}_{16}: \mathrm{C}_{27}$ & $<0.1$ \\
\hline & $\mathrm{C}_{17}: \mathrm{C}_{26}$ & 0.1 \\
\hline & $\mathrm{C}_{18}: \mathrm{C}_{25}$ & 0.1 \\
\hline & $\mathrm{C}_{19}: \mathrm{C}_{24}$ & 0.1 \\
\hline & $\mathrm{C}_{20}: \mathrm{C}_{23}$ & 0.2 \\
\hline & $\mathrm{C}_{21}: \mathrm{C}_{22}$ & 0.7 \\
\hline & $\mathrm{C}_{22}: \mathrm{C}_{21}$ & 0.2 \\
\hline & $\mathrm{C}_{23}: \mathrm{C}_{20}$ & 0.1 \\
\hline & $\mathrm{C}_{24}: \mathrm{C}_{19}$ & $<0.1$ \\
\hline & $\mathrm{C}_{25}: \mathrm{C}_{18}$ & $<0.1$ \\
\hline \multirow[t]{5}{*}{ wax $\mathrm{C}_{44}$} & & 19.1 \\
\hline & $\mathrm{C}_{16}: \mathrm{C}_{28}$ & 0.9 \\
\hline & $\mathrm{C}_{18}: \mathrm{C}_{26}$ & 0.5 \\
\hline & $\mathrm{C}_{20}: \mathrm{C}_{24}$ & 1.7 \\
\hline & $\mathrm{C}_{22}: \mathrm{C}_{22}$ & 16.0 \\
\hline \multirow[t]{6}{*}{$\operatorname{wax} \mathrm{C}_{46}$} & & 5.3 \\
\hline & $C_{16}: C_{30}$ & 0.2 \\
\hline & $\mathrm{C}_{18}: \mathrm{C}_{28}$ & 0.2 \\
\hline & $\mathrm{C}_{20}: \mathrm{C}_{26}$ & 0.2 \\
\hline & $\mathrm{C}_{22}: \mathrm{C}_{24}$ & 1.8 \\
\hline & $\mathrm{C}_{24}: \mathrm{C}_{22}$ & 2.9 \\
\hline
\end{tabular}

a tr, traces.

acylesters of glycerol, as well as sterol esters and sterol glycosides, were also present in important amounts. The structures of the main lipophilic compounds identified in the curaua extract are shown in Figure 3. The $\omega$-hydroxy fatty acids both in free or in esterified form (forming esters with both fatty
Table 4. Composition and Abundance $(\mathrm{mg} / \mathrm{kg})$ of the Different $\omega$-Hydroxy Monoesters Identified in Curaua Fibers

\begin{tabular}{ccc}
\hline$\omega$-hydroxy monoester & $\begin{array}{c}\omega \text {-hydroxy fatty acid: } \\
\text { fatty alcohol }\end{array}$ & abundance \\
\hline$\omega$-hydroxy monoester $\mathrm{C}_{36}$ & $\omega$-OHC $16: \mathrm{C}_{20}$ & 29.1 \\
$\omega$-hydroxy monoester $\mathrm{C}_{37}$ & $\omega$-OHC & 29.1 \\
& & 3.0 \\
$\omega$-hydroxy monoester $\mathrm{C}_{38}$ & $\omega-\mathrm{OHC}_{16}: \mathrm{C}_{22}$ & 3.0 \\
& $\omega-\mathrm{OHC}_{18}: \mathrm{C}_{20}$ & 229.8 \\
$\omega$-hydroxy monoester $\mathrm{C}_{40}$ & $\omega-\mathrm{OHC}_{16}: \mathrm{C}_{24}$ & 223.9 \\
& $\omega-\mathrm{OHC}_{18}: \mathrm{C}_{22}$ & 5.9 \\
& $\omega-\mathrm{OHC}_{20}: \mathrm{C}_{20}$ & 55.6 \\
$\omega$-hydroxy monoester $\mathrm{C}_{42}$ & $\omega-\mathrm{OHC}_{16}: \mathrm{C}_{26}$ & 35.2 \\
& $\omega-\mathrm{OHC}_{18}: \mathrm{C}_{24}$ & 0.9 \\
& $\omega-\mathrm{OHC}_{20}: \mathrm{C}_{22}$ & 11.7 \\
& $\omega-\mathrm{OHC}_{22}: \mathrm{C}_{20}$ & 4.8 \\
& $\omega-\mathrm{OHC}_{20}: \mathrm{C}_{24}$ & 5.7 \\
& $\omega-\mathrm{OHC}_{12}: \mathrm{C}_{22}$ & 0.9 \\
& & 0.3 \\
& & 0.1 \\
& & 0.2 \\
\hline
\end{tabular}

alcohols and glycerol) was the main series of compounds present in the extracts.

The series of free fatty acids was present in the range from $n$-tetradecanoic $\left(\mathrm{C}_{14}\right)$ to $n$-tetracosanoic $\left(\mathrm{C}_{24}\right)$ acids, with strong even-over-odd carbon atom predominance. Stearic acid $\left(\mathrm{C}_{18: 0}\right)$ and palmitic acid $\left(\mathrm{C}_{16: 0}\right)$ were the most abundant fatty acids followed by $n$-docosanoic $\left(\mathrm{C}_{22}\right)$ and $n$-tetracosanoic $\left(\mathrm{C}_{24}\right)$ acids. Unsaturated fatty acids, such as palmitoleic $\left(\mathrm{C}_{16: 1}\right)$, oleic $\left(\mathrm{C}_{18 \text { : }}\right.$ 1), and linoleic $\left(\mathrm{C}_{18: 2}\right)$ acids, were also present, oleic acid being especially abundant.

Hydroxy fatty acids ( $\alpha$ - and $\omega$-) were also identified in the curaua extracts, with a high abundance of the $\omega$-hydroxy fatty acids and the presence of exclusively the even carbon atom number homologues. $\alpha$-Hydroxyfatty acids were present in the range from 2-hydroxyeicosanoic acid $\left(\mathrm{C}_{20}\right)$ to 2-hydroxyhexacosanoic acid $\left(\mathrm{C}_{26}\right)$ with a maximum at $\mathrm{C}_{24}$, whereas the $\omega$-hydroxyfatty acids were identified in the range from 16hydroxyhexadecanoic acid $\left(\mathrm{C}_{16}\right)$ to 30-hydroxytriacontanoic acid $\left(\mathrm{C}_{30}\right)$ with a maximum at $\mathrm{C}_{26}$.

Waxes (esters of fatty acids to fatty alcohols) were also important components of the curaua fiber extracts and were found in the range from $\mathrm{C}_{36}$ to $\mathrm{C}_{46}$. Among the waxes, the $\mathrm{GC} /$ MS analysis revealed that each chromatographic peak consisted of a complex mixture of different long chain fatty acids esterified to different long chain fatty alcohols. The identification and quantification of the individual long chain esters in each chromatographic peak were resolved based on the mass spectra of the peaks. The mass spectra of long chain esters are characterized by a base peak produced by a rearrangement process involving the transfer of $2 \mathrm{H}$ atoms from the alcohol chain to the acid chain giving a protonated acid ion $(24,43-$ $45)$. Therefore, the base peak gives the number of carbon atoms in the acid moiety and the molecular ion the total number of carbon atoms in the ester. It is possible then to determine the individual contribution of the esters to every chromatographic peak by mass spectrometric determination of the molecular ion and the base peak. Quantification of individual esters was accomplished by integrating areas in the chromatographic profiles of ions characteristic for the acidic moiety. The detailed structural composition and abundance of the high molecular weight waxes identified in the curaua fiber is shown in Table 3. The esterified fatty acids ranged from $\mathrm{C}_{12}$ to $\mathrm{C}_{25}$, and the 


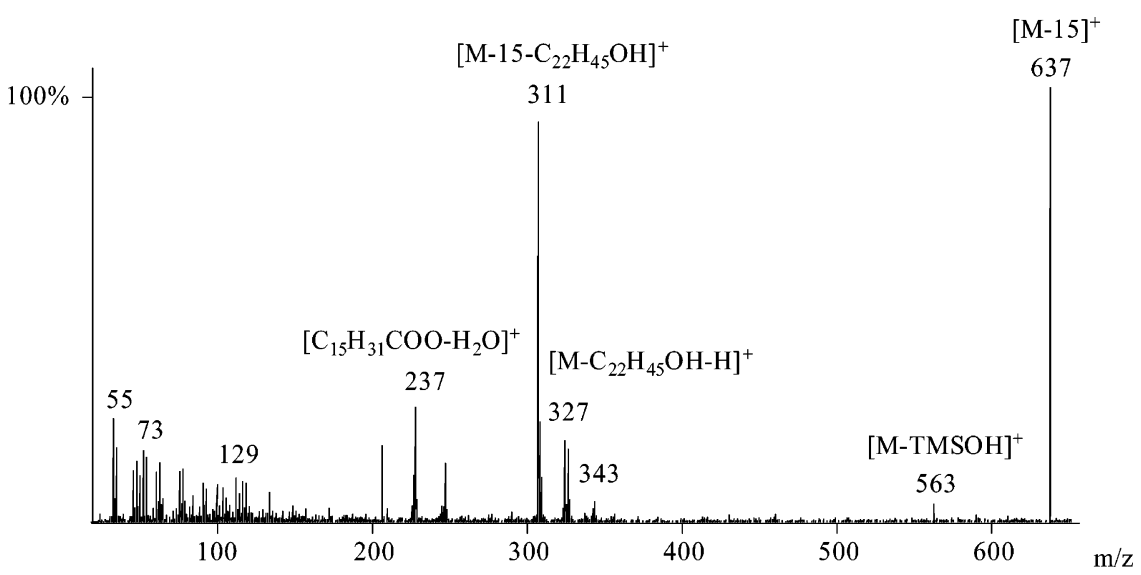

Figure 4. Mass spectrum of trimethylsilylated hydroxy monoester $\mathrm{C}_{38}$.

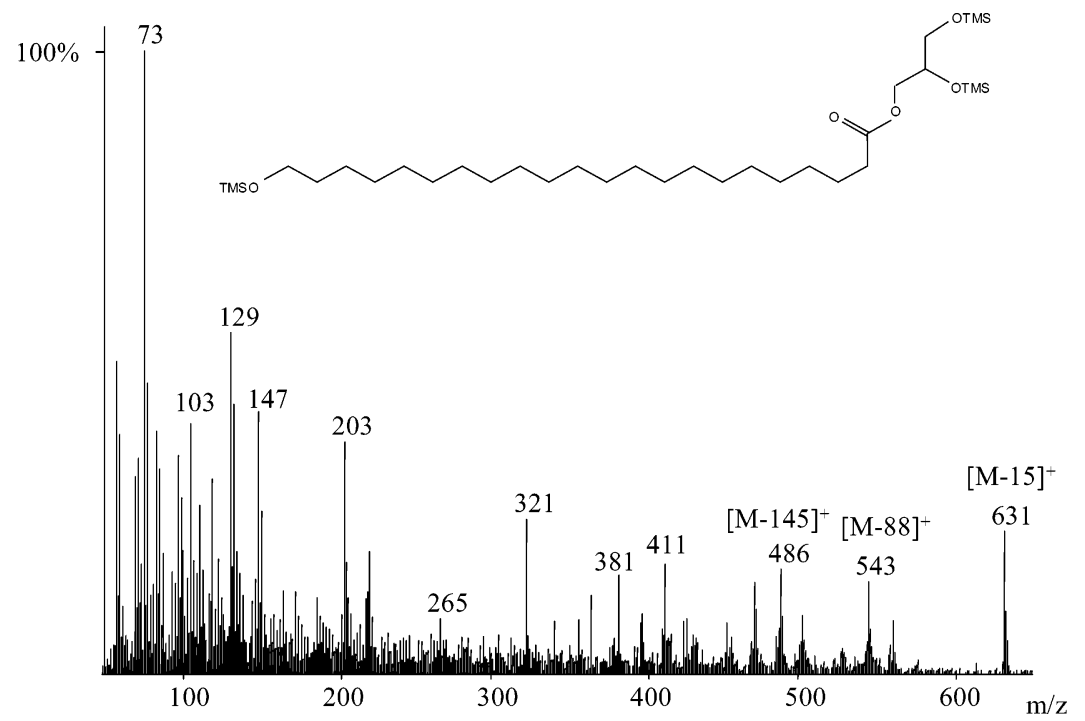

Figure 5. Mass spectrum and structure of the TMSi ether derivative of 1-mono(22-hydroxydocosanoyl)glycerol.

esterified fatty alcohols ranged from $\mathrm{C}_{16}$ to $\mathrm{C}_{30}$. Waxes with unsaturated fatty acids $\left(\mathrm{C}_{40: 1}\right.$ and $\left.\mathrm{C}_{42: 1}\right)$ were also found in lower amounts, the unsaturated fatty acid being in all cases oleic acid.

Other waxes, consisting of a complex mixture of different long chain $\omega$-hydroxy fatty acids esterified to different long chain fatty alcohols, were also found in high amounts. These waxes are similar to those described among the waxes normally secreted by bees $(46-48)$. The mass spectrum of the TMSi ether derivative of a selected $\omega$-hydroxy monoester $\left(\mathrm{C}_{38}\right)$ is shown in Figure 4. The mass spectrum of this compound is characterized by a base peak at $\mathrm{m} / \mathrm{z} 637$ corresponding to the $[\mathrm{M}-15]^{+}$ fragment ion and a fragment formed by the loss of the fatty alcohol at $\mathrm{m} / \mathrm{z}$ 311. The elimination of trimethylsilanol (TMSOH) from the molecular ions also can be observed at $\mathrm{m} / \mathrm{z}$ $563(49,50)$. As occurred with the esters of fatty acids with fatty alcohols, each chromatographic peak is composed of a complex mixture of compounds. Quantification of individual compounds was performed by integrating the chromatographic profiles of the characteristic ions. The detailed structural composition of the $\omega$-hydroxy monoesters is shown in Table 4. The esterified $\omega$-hydroxy fatty acids ranged from $\mathrm{C}_{16}$ to $\mathrm{C}_{22}$, and the esterified fatty alcohols ranged from $\mathrm{C}_{20}$ to $\mathrm{C}_{26}$.

$\omega$-Hydroxy fatty acids esterified to glycerol were also found in high amounts in the curaua fiber. The mass spectra of the TMSi derivatives of $\omega$-hydroxy acylesters of glycerol are characterized by the presence of an abundant fragment arising from the loss of a methyl group at $[\mathrm{M}-15]^{+}$. The cleavage between the $\mathrm{C}-2$ and the $\mathrm{C}-3$ carbons in the glyceryl moiety gives rise to the fragments at $m / z, 103$ and $[\mathrm{M}-103]^{+}$. Other diagnostic ions are derived from the glyceryl moiety, i.e., at $\mathrm{m} / \mathrm{z} 205$ as a result of the cleavage between the C-2 and the $\mathrm{C}-1$ (the esterified carbon) and at $\mathrm{m} / \mathrm{z} 219$ due to the loss of the acyloxy moiety. The same loss of the acyloxy group from $\mathrm{M}^{+} \bullet$ and $\mathrm{M}-15^{+}$, but with the $\mathrm{H}$ rearrangement, gives rise to the ions at $\mathrm{m} / \mathrm{z} 218$ and 203, respectively. Other significant ions in the low-mass region occur at $\mathrm{m} / \mathrm{z} 73$ (the TMSi group), $\mathrm{m} / \mathrm{z}$ 129 (the glycerol carbon backbone with a TMSi group $\left[\mathrm{H}_{2} \mathrm{C}=\right.$ $\left.\mathrm{CH}-\mathrm{CH}=\mathrm{O}^{+}-\mathrm{Si}\left(\mathrm{CH}_{3}\right)_{3}\right]$ ), and $m / z, 147$ (produced by the rearrangement of two TMSi groups) (51). The $\omega$-hydroxy fatty acids esterified to the glycerol range from $\mathrm{C}_{22}$ to $\mathrm{C}_{28}$. The structure and mass spectrum of the TMSi derivative of 1-mono(22-hydroxydocosanoyl)glycerol are shown in Figure 5.

$n$-Fatty alcohols ranging from $\mathrm{C}_{20}$ to $\mathrm{C}_{28}$ were present in the curaua extracts with the presence of only the even carbon atom homologues, docosanol $\left(\mathrm{C}_{22}\right)$ and tetracosanol $\left(\mathrm{C}_{24}\right)$ being the most abundant. Monoglycerides, accounting for $690.7 \mathrm{mg} / \mathrm{kg}$ of the fibers, were present in important amounts, from $\mathrm{C}_{14}$ to $\mathrm{C}_{30}, \mathrm{C}_{22}$ (1-monodocosanoylglycerol) being the most prominent. $\mathrm{Di}$ - and triglycerides were only identified in trace amounts.

Sterols were also present among the lipids of curaua fibers in high amounts. Sitosterol was the most abundant among the free sterols with the presence of minor amounts of stigmastanol, ergostanol, and campesterol. Lower amounts of sitosterol and campesterol could also be found in ester form. Sterol glycosides, 
such as sitosteryl and campesteryl $3 \beta$-D-glucopyranosides, were also identified in high amounts, the former being the most predominant. The identification of steryl glycosides was accomplished, after BSTFA derivatization of the lipid extract, by comparison with the mass spectra and relative retention times of authentic standards (52). Finally, other compounds identified among the curaua fiber extractives were $\alpha$-tocopherol, several steroid hydrocarbons, and steroid ketones, as reflected in Table 2.

In conclusion, curaua fiber is characterized by a high content of holocellulose and $\alpha$-cellulose and low lignin content, which would make this fiber suitable for papermaking. Moreover, the lignin composition indicates a slight predominance of S-lignin units $(\mathrm{S} / \mathrm{G}$ molar ratio of 1.4$)$. On the other hand, the high extractive content can be considered as a detrimental aspect; however, most of the acetone extracts are due to polar compounds and only $1.3 \%$ corresponds to lipophilic compounds. Indeed, most of the lipophilic compounds are easily saponifiable and, therefore, can be hydrolyzed and dissolved during alkaline cooking.

\section{ACKNOWLEDGMENT}

We thank CELESA (Tortosa, Spain) for providing the curaua fibers.

\section{LITERATURE CITED}

(1) Fujihashi, G. A.; Barbosa, W. L. R. Ananas erectifolius (curauá): Padronização dos extractos, frações e do material vegetal. Rev. Científica UFPA 2002, 3.

(2) Silva, G. S.; Assis, M. B.; Barbosa, W. L. R. Investigação fitoquímica e microbiologica da espécie Ananas erectifolius (curauá). Rev. Virtual Iniciação Acad. UFPA 2001, 1.

(3) Hoareau, W.; Trindade, W. G.; Siegmund, B.; Castellan, A.; Frollini, E. Sugar cane bagasse and curaua lignins oxidized by chlorine dioxide and reacted with furfuryl alcohol: Characterization and stability. Polym. Degrad. Stab. 2004, 86, 567-576.

(4) Leao, A. L.; Rowell, R.; Tavares, N. Applications of natural fibres in automotive industry in Brazil-Thermoforming process. In Science and Technology of Polymers Advanced Materials. Emerging Technologies and Business Opportunities; Prasad, P. N., Mark, J. E., Kandil, S. H., Kafafi, Z. H., Eds.; Plenum Press: New York, 1998; pp 755-761.

(5) Kelley, S. S.; Rowell, R. M.; Davis, M.; Jurich, Ch. K.; Ibach, R. Rapid analysis of the chemical composition of agricultural fibers using near infrared spectroscopy and pyrolysis molecular beam mass spectrometry. Biomass Bioenergy 2004, 27, 77-88.

(6) González-Vila, F. J.; Almendros, G.; del Río, J. C; Martín, F.; Gutiérrez, A.; Romero, J. Ease of delignification assessment of wood from different Eucalyptus species by pyrolysis (TMAH)GC/MS and CP/MAS ${ }^{13} \mathrm{C}$ NMR spectrometry. J. Anal. Appl. Pyrol. 1999, 49, 295-305.

(7) del Río, J. C.; Gutiérrez, A.; Hernando, M.; Landín, P.; Romero, J.; Martínez, A. T. Determining the influence of eucalypt lignin composition in paper pulp yield using Py-GC/MS. J. Anal. Appl. Pyrol. 2005, 74, 110-115.

(8) Nimz, H. Beech lignin- Proposal of a constitutional scheme. Angew. Chem. Int. Ed. 1974, 13, 313-321.

(9) Adler, E. Lignin chemistry-Past, present and future. Wood Sci. Technol. 1977, 11, 169-218.

(10) Tsutsumi, Y.; Kondo, R.; Sakai, K.; Imamura, H. The difference of reactivity between syringyl lignin and guaiacyl lignin in alkaline systems. Holzforschung 1995, 49, 423-428.

(11) Hillis, W. E.; Sumimoto, M. Effect of extractives on pulping. In Natural Products of Woody Plants II; Rowe, J. W., Ed.; Springer-Verlag: Berlin, Germany, 1989; pp 880-920.

(12) Back, E. L.; Allen, L. H. Pitch Control, Wood Resin and Deresination; Tappi Press: Atlanta, GA, 2000.
(13) Gutiérrez, A.; del Río, J. C.; Martínez, M. J.; Martínez, A. T. The biotechnological control of pitch in paper pulp manufacturing. Trends Biotechnol. 2001, 19, 340-348.

(14) Ali, M.; Sreekrishnan, T. R. Aquatic toxicity from pulp and paper mill effluents: A review. Adv. Environ. Res. 2001, 5, 175-196.

(15) Rigol, A.; La Torre, A.; Lacorte, S.; Barceló, D. Bioluminiscence inhibition assays for toxicity screening of wood extractives and biocides in paper mill process waters. Environ. Toxicol. Chem. 2003, 23, 339-347.

(16) Faix, O.; Meier, D.; Fortmann, I. Thermal degradation products of wood. A collection of electron of electron-impact (EI) mass spectra of monomeric lignin derived products. Holz Roh-Werkst. 1990, 48, 351-354.

(17) Ralph, J.; Hatfield, R. D. Pyrolysis-GC/MS characterization of forage materials. J. Agric. Food Chem. 1991, 39, 1426-1437.

(18) Gutiérrez, A.; del Río, J. C.; González-Vila, F. J.; Martín, F. Analysis of lipophilic extractives from wood and pitch deposits by solid-phase extraction and gas chromatography. J. Chromatogr. A 1998, 823, 449-455.

(19) Browning, B. L. Methods of Wood Chemistry; Wiley-Interscience Publishers: New York, 1967; Vol. II.

(20) Technical Association of the Pulp and Paper Industry. Test Methods, 1992-1993; TAPPI: Atlanta, GA, 1993.

(21) Gutiérrez, A.; Rodríguez, I. M.; del Río, J. C. Chemical characterization of lignin and lipid fractions in kenaf bast fibers used for manufacturing high-quality papers. J. Agric. Food Chem. 2004, 52, 4764-4773.

(22) van Dam, J. E. G.; van Vilsteren, G. E. T.; Zomers, F. H. A.; Shannon, W. B.; Hamilton, I. T. Increased Application of Domestically Produced Plant Fibers in Textiles, Pulp and Paper Production and Composite Materials; Directorate-General XII, Science, Research and Development, European Commision: Brussels, 1994.

(23) del Río, J. C.; Gutiérrez, A. Chemical composition of abaca (Musa textilis) leaf fibers used for manufacturing of high quality paper pulps. J. Agric. Food Chem. 2006, 54, 4600-4610.

(24) Gutiérrez. A.; del Río, J. C. Lipids from flax fibers and their fate in alkaline pulping. J. Agric. Food Chem. 2003, 51, 49654971.

(25) Gutiérrez. A.; del Río, J. C. Lipids from flax fibers and their fate in alkaline pulping. J. Agric. Food Chem. 2003, 51, 69116914.

(26) Gutiérrez, A.; Rodríguez, I. M.; del Río, J. C. Chemical characterization of lignin and lipid fractions in industrial hemp bast fibers used for manufacturing high-quality paper pulps. $J$. Agric. Food Chem. 2006, 54, 2138-2144.

(27) Moore, G. Nonwood Fibre Applications in Papermaking; Pira International: Leatherhead, Surrey, United Kingdom, 1996.

(28) del Río, J. C.; Martín, F.; González-Vila, F. J. Thermally assisted hydrolysis and alkylation as a novel pyrolytic approach for the structural characterization of natural biopolymers and geomacromolecules. Trends Anal. Chem. 1996, 15, 70-79.

(29) Lam, T. B. T.; Kadoya, K.; Liyama, K. Bonding of hydroxycinamic acids to lignin: ferulic and p-coumaric acids are predominantly linked at the benzyl position of lignin, not the $\beta$-position, in grass cell walls. Phytochemistry 2001, 57, 987992.

(30) Sun, R. C.; Sun, X. F.; Zhang, S. H. Quantitative determination of hydroxycinnamic acids in wheat, rice, rye, and barley straws, maize stems, oil palm frond fiber, and fast-growing poplar wood. J. Agric. Food Chem. 2001, 49, 5122-5129.

(31) Grabber, J. H.; Ralph, J.; Hatfield, R. D. Cross-linking of maize walls by ferulate dimerization and incorporation into lignin. $J$. Agric. Food Chem. 2000, 48, 6106-6113.

(32) Scalbert, A.; Monties, B.; Lallemand, J. Y.; Guittet, R.; Rolando, C. Ether linkage between phenolic acids and lignin fractions from wheat straw. Phytochemistry 1985, 24, 1359-1362. 
(33) Sun, R. C.; Sun, X. F.; Wang, S. Q.; Zhu, W.; Wang, X. Y. Ester and ether linkages between hydroxycinnamic acids and lignins from wheat, rice, rye, and barley straws, maize stems, and fast-growing poplar wood. Ind. Crop Prod. 2002, 15, 179188.

(34) Lam, T. B. T.; liyama, K.; Stone, B. A. Cinnamic acids bridges between cell wall polymers in wheat and Phalaris internodes. Phytochemistry 1992, 31, 1179-1183.

(35) del Río, J. C.; McKinney, D. E.; Knicker, H.; Nanny, M. A.; Minard, R. D.; Hatcher, P. G. Structural characterization of bioand geo-macromolecules by off-line thermochemolysis with tetramethylammonium hydroxide. J. Chromatogr. A 1998, 823, 433-448.

(36) Martín, F.; del Río, J. C.; González-Vila, F. J.; Verdejo, T. Thermally assisted hydrolysis and alkylation of lignins in the presence of tetra-alkylammonium hydroxides. J. Anal. Appl. Pyrol. 1995, 35, 1-13.

(37) Challinor, J. M. Characterization of wood by pyrolysis derivatization-gas chromatography/ mass spectrometry. J. Anal. Appl. Pyrol. 1995, 35, 93-107.

(38) Clifford, D. J.; Carson, D. M.; Mackinney, D. E.; Bortiatynski, J. M.; Hatcher, P. G. A new rapid technique for the characterization of lignin in vascular plants: Thermochemolysis with tetramethylammonium hydroxide (TMAH). Org. Geochem. 1995, $23,169-175$.

(39) Ralph, J.; Hatfield, R. D.; Quideau, S.; Helm, R. F.; Grabber, J. H.; Jung, H.-J. G. Pathway of p-coumaric acid incorporation into maize lignin as revealed by NMR. J. Chem. Soc. 1994, 34, 1-12.

(40) Crestini, C.; Argyropoulos, D. S. Structural analysis of wheat straw lignin by quantitative ${ }^{31} \mathrm{P}$ and $2 \mathrm{D}$ NMR spectroscopy. The occurrence of ester bonds and $\alpha-\mathrm{O}-4$ substructures. J. Agric. Food Chem. 1997, 45, 1212-1219.

(41) Lu, F. C.; Ralph, J. Detection and determination of p-coumaroylated units in lignins. J. Agric. Food Chem. 1999, 47, 19881992.

(42) Grabber, J. H.; Quideau, S.; Ralph, J. p-Coumaroylated syringyl units in maize lignin: Implications for $\beta$-ether cleavage by thioacidolysis. Phytochemistry 1996, 43, 1189-1194.

(43) Sharkey, A. G., Jr.; Shultz, J. L.; Friedel, R. A. Mass spectra of esters. Formation of rearrangement ions. Anal. Chem. 1959, 31, 87-94.
(44) Moldovan, Z.; Jover, E.; Bayona, J. M. Systematic characterization of long-chain aliphatic esters of wool wax by gas chromatography-electron impact ionisation mass spectrometry. J. Chromatogr. A 2002, 952, 193-204.

(45) Reiter, B.; Lechner, M.; Lorbeer, E.; Aichholz, R. Isolation ad characterization of wax esters in fennel and caraway seed oils by SPE-GC. J. High Resolut. Chromatogr. 1999, 22, 514-520.

(46) Tulloch, A. P. The composition of beeswax and other waxes secreted by insects. Lipids $\mathbf{1 9 6 9}, 5,247-258$.

(47) Tulloch, A. P. Beeswax: Structure of the esters and their component hydroxy acids and diols. Chem. Phys. Lipids 1971, 6, 235-265.

(48) Aichholz, R.; Lorbeer, E. Investigation of combwax of honeybees with high-temperature gas chromatography and high-temperature gas chromatography-chemical ionization mass spectrometry: I. High-temperature gas chromatography. J. Chromatogr. A 1999, $855,601-615$.

(49) Aichholz, R.; Lorbeer, E. Investigation of combwax of honeybees with high-temperature gas chromatography and high-temperature gas chromatography-chemical ionization mass spectrometry: II. High-temperature gas chromatography-chemical ionization mass spectrometry. J. Chromatogr. A 2000, 883, 75-88.

(50) Kimpe, K.; Jacobs, P. A.; Waelkens, M. Mass spectrometric methods prove the use of beeswax and ruminant fat in late Roman cooking pots. J. Chromatogr. A 2002, 968, 151-160.

(51) Graça, J.; Schreiber, L.; Rodrigues, J.; Pereira, H. Glycerol and glyceryl esters of $\omega$-hydroxyacids in cutins. Phytochemistry 2002, $61,205-215$

(52) Gutiérrez, A.; del Río, J. C. Gas chromatography/mass spectrometry demonstration of steryl glycosides in eucalypt wood, kraft pulp and process liquids. Rapid Commun. Mass Spectrom. 2001, 15, 2515-2520.

Received for review September 19, 2006. Revised manuscript received December 21, 2006. Accepted December 21, 2006. This study has been supported by the Spanish MEC (Project AGL2005-01748).

JF062677X 